\title{
HUBUNGAN ANC DENGAN KEJADIAN PREEKLAMPSIA PADA IBU HAMIL
}

\author{
Nurul Muthoharoh ${ }^{1^{*}}$, Sita Safitri, A.Fahira Nur ${ }^{2}$ \\ ${ }^{1}$ Mahasiswa Kebidanan STIKES Widya Nusantara Palu \\ ${ }^{2}$ Bagian Kebidanan STIKES Widya Nusantara Palu \\ ${ }^{\star} E$-mail : nurulmuthoharoh47@gmail.com
}

Angka Kematian lbu (AKI) merupakan salah satu indikator untuk melihat derajat kesehatan perempuan. AKI merupakan salah satu target yang telah ditentukan dalam tujuan pembangunan millennium yaitu tujuan ke 5. Terdapat dua kategori kematian ibu yaitu disebabkan oleh penyebab langsung obstetri yaitu kematian yang diakibatkan langsung oleh kehamilan dan persalinannya, dan kematian yang disebabkan oeh penyebab tidak langsung yaitu kematian yang terjadi pada ibu hamil yang disebabkan oleh penyakit dan bukan oleh kehamilan atau persalinannya. salah satu masalah yang berdampak pada komplikasi kehamilan yaitu preeklampsia pada ibu hamil yang disebabkan oleh beberapa faktor risiko ${ }^{2}$.

Berikut ini penulis akan membahas tentang hubungan ANC dengan kejadian preeklamsia pada ibu hamil.

\section{Tinjauan tentang preeklamsia}

Preeklampsia merupakan kumpulan gejala yang timbul pada ibu hamil, bersalin dan dalam masa nifas yang terdiri dari trias: hipertensi, proteinuri, dan edema, yang kadang-kadang disertai konvulsi sampai koma. Ibu tersebut tidak menunjukkan tanda tanda kelainan-kelainan vascular atau hipertensi sebelumnya. ${ }^{6}$

Preeklampsia merupakan salah satu penyebab kematian ibu hamil, dengan predisposisi yaitu kehamilan ganda, diabetes melitus, riwayat hipertensi ibu, molahidatidosa, obesitas, sosial ekonomi rendah, paritas ibu dan primigravida muda umur $<20$ tahun dan pada primigravida tua umur $>35$ tahun. ${ }^{1}$ 
preeklamsia dapat di bedakan menjadi 2 yaitu preeklamsia ringan, dan preeklamsia berat. Preklamsi ringan ditandai dengan : kehamilan lebih dari 20 minggu; kenaikan tekanana darah 140/90 $\mathrm{mmHg}$ atau lebih dangan pemeriksaan 2 kali selang 6 jam dalam keadaan istirahat (untuk pemeriksaan pertama dilakukan 2 kali setelah istirahat 10 menit); edema tekan pada tungkai (pretibia), dinding perut, lumbosakral, wajah atau tangan; proteinuria lebih 0,3 gr/liter/2jam, kualitatif +2 . Preeklamsi berat di tandai dengan tekanan darah sistolik $>160 \mathrm{mmHg}$, diastolik $>110 \mathrm{mmHg}$, peningkatan kadar enzim hati atau ikterus, trombosit $<100.000 / \mathrm{mm}^{3}$, oliguria $<400 \mathrm{ml} / 24 \mathrm{jam}$, protein urine $>3 \mathrm{gr} / \mathrm{liter}$, nyeri episgtastrium, skotoma dan gangguan visus lain atau nyeri frontal yang berat, perdarahan retina, odem pulmonum. ${ }^{4}$

Jika preeklamsi ringan dan berat tidak dapat ditangani dengan baik pada ibu hamil, maka akan dapat mengakibatkan terjadinya eklamsi pada ibu hamil. ${ }^{4}$

\begin{tabular}{lll} 
TABEL 49-2 Gangguan & Hipertensif Selama Kehamilan: Indikasi Keparahan \\
\hline Kelainan & Ringan & Berat \\
\hline Tekanan darah diastole & $<100 \mathrm{~mm} \mathrm{Hg}$ & $110 \mathrm{~mm} \mathrm{Hg}$ atau lebih \\
Proteinuria & Sekelumit sampai $1+$ & Menetap $2+$ atau lebih \\
Sakit kepala & Tidak ada & Ada \\
Gangguan penglihatan & Tidak ada & Ada \\
Nyeri abdomen atas & Tidak ada & Ada \\
Oliguria & Tidak ada & Ada \\
Kejang & Tidak ada & Ada (eklamsia) \\
Kreatinin serum & Normal & Meningkat \\
Trombositopenia & Tidak ada & Ada \\
Peningkatan enzim hati & Minimal & Nyata \\
Hambatan pertumbuhan & Tidak ada & Jelas \\
janin & Tidak ada & Ada \\
Edema paru & gambar perbedaan preeklamsia ringan dan berat.
\end{tabular}

\section{Tinjauan tentang faktor resiko preeklamsia}

Kejadian preeklamsia pada ibu hamil berhubungan dengan beberapa faktor penting, Yaitu di antaranya umur, paritas, pengetahuan ibu, riwayat hipertensi, dan pemeriksaan ANC. ${ }^{6}$

Pelayanan ANC berpengaruh pada kejadian preeklampsia. hal ini dapat terjadi karena masih belum maksimalnya pelayanan ANC yang diberikan kepada ibu hamil, sehingga petugas kesehatan kesulitan untuk mendeteksi dan membedakan antara hipertensi kronis dengan preeklsampsia., 
Preeklampsia dan eklampsia merupakan komplikasi kehamilan berkelanjutan, oleh karena itu melalui antenatal care yang bertujuan untuk mencegah perkembangan preeklampsia, atau setidaknya dapat mendeteksi dini sehingga dapat mengurangi kejadian kesakitan. Pada tingkat permulaan preeklampsia tidak memberikan gejala yang dapat dirasakan oleh pasien sendiri, maka diagnosa dini hanya dapat dibuat dengan antenatal care. Jika calon ibu melakukan kunjungan setiap minggu ke klinik prenatal selama 4-6 minggu terakhir kehamilannya, ada kesempatan untuk melakukan tes proteinuri, mengukur tekanan darah, dan memeriksa tanda udema. Setelah diketahui diagnosa dini, perlu segera dilakukan penanganan untuk mencegah masuk ke dalam eklampsia. ${ }^{5}$

\section{Tinjauan Tentang pelayanan ANC Terhadap preeklamsia}

Preeklampsia merupakan gangguan terkait kehamilan berupa tekanan darah tinggi yang disertai proteinuria dan pembengkakan akibat penumpukan cairan (edema) baik pada tungkai, tangan, bahkan seluruh tubuh dan kadang-kadang disertai konvulsi sampai koma. Kondisi ini tidak hanya berbahaya bagi ibu hamil tetapi juga janin, terutama pada preeklampsia berat. ${ }^{6}$

kejadian preeklamsia dapat terjadi lebih tinggi dikarenakan kurangnya pelayanan antenatal care (ANC). Kunjungan kehamilan atau ANC (Antenatal Care) merupakan salah satu upaya yang dapat dilakukan sebagai pencegahan awal dari preeklampsia. Data atau informasi awal terkait dengan tekanan darah sebelum hamil akan sangat membantu petugas kesehatan untuk membedakan antara hipertensi kronis dengan preeklsampsia. ${ }^{1}$

seorang ibu hamil yang mendapatkan pelayanan antenatal dengan pola standar 4 kali selama kehamilan, yaitu 1 kali pada triwulan pertama, 1 kali pada triwulan kedua dan 2 kali pada triwulan ketiga. Pelayanan antenatal yang berkualitas (sesuai standar) dapat mendeteksi gejala dan tanda yang berkembang selama kehamilan. Jika ibu tidak memeriksakan diri hingga paruh kedua masa kehamilan, 
diagnosis hiptertensi kronis akan sulit dibuat karena tekanan darah biasanya menurun selama trimester kedua dan ketiga pada wanita dengan hipertensi. Kunjungan antenatal kurang dari 4 kali dengan demikian akan meningkatkan risiko menderita preklampsia atau eklampsia. $^{5}$

Hasil yang diperoleh bahwa kunjungan kehamilan/ANC merupakan faktor risiko kejadian preeklampsia. Berdasarkan hasil uji statistik diperoleh nilai OR yaitu 7,933. Hal ini menunjukan bahwa Kunjungan kehamilan Antenatal Care (ANC) merupakan faktor risiko kejadian preeklampsia dengan kata lain berisiko 7,933 kali lebih besar untuk mengalami preeklampsia di banding dengan yang tidak melakukan kunjungna kehamilan/ANC $>2$ kali $^{5}$

hasil perhitungan yang telah dilakukan didapat OR sebesar 9,6 kali untuk mengalami preeklampsia, yaitu bagi ibu hamil yang tidak rutin memeriksakan kehamilannya mempunyai risiko 9,6 kali untuk mengalami preeklampsia dibanding dengan ibu hamil yang rutin ANC. Pelayanan ANC berpengaruh pada kejadian preeklampsia dapat terjadi karena masih belum maksimalnya pelayanan ANC yang diberikan kepada ibu hamil. ${ }^{5}$

Upaya untuk mengurangi kejadian preeklamsia pada ibu hamil, yaitu dengan penyuluhan rutin pada seluruh lapisan masyarakat tentang pentingnya pelayanan ANC pada ibu hamil, hal ini dilakukan agar tenaga kesehatan khususnya bidan, dapat melakukan deteksi dini pada ibu khusunya untuk mengurangi kejadian preeklamsia pada ibu hamil. 


\section{DAFTAR PUSTAKA}

1. A.Fahira Nur \& Adhar Arifuddin (2017). Faktor Risiko Kejadian Preeklampsia Pada Ibu Hamil Di Rsu Anutapura Kota Palu. Jurnal Kesehatan Tadulako Vol. 3 No. 2, Juli 2017 : 1-75 http://jurnal.untad.ac.id/jurnal/index.php/HealthyTadulako/articl e/view/8750 Diakses Pada Tanggal 12 Oktober 2019.

2. Dien Gusta Anggraeni Nursal, Pratiwi Tamela, Fitrayeni (2015). Faktor Resiko Kejadian Preeklamsia Pada Ibu Hamil Di RSUP DR. M. Djamil Padang Tahun 2014. Jurnal Kesehatan Masyarakat Andalas Vol 10 No 1, Oktober 2015 : 38-44

Http://Jurnal.Fkm.Unand.Ac.Id/Index.Php/Jkma/Article/View/1 61/157 Di Akses Pada Tanggal 12 Oktober 2019.

3. Ernina Puspa Isnanda, Meitria Syahadatina Noor, Musafah. (2012). Hubungan Pelayanan Antenatal Care (ANC) Dengan Kejadian Preeklamsia Ibu Hamil Di Rsud Ulin Banjarmasin. Jurnal Kesehatan Masyarakat Indonesia. Maret 2012: 67-72 Https://Docplayer.Info/35662401-Hubungan-Pelayanan Antenatal-Care-Anc-Dengan-Kejadian-Preeklampsia-lbuHamil-Di-Rsud-Ulin-Banjarmasin.Html. Di Akses 12 Oktober 2019.

4. Leveno, dkk. 2009. obstetri wiliams. Jakarta:buku kedokteran EGC.

5. Nelyta Oktavianisya. (2016).Pengaruh Kualitas Anc Dan Riwayat Morbiditas Maternal Terhadap Morbiditas Maternal Di Kabupaten Sidoarjo. Jurnal kesehatan wiraraja medika. Vol 6 No 2, Januari 2017 : 78-85 http://garuda.ristekdikti.go.id/documents/detail/1078262. Di akses 13 oktober 2019.

6. Tigor H. Situmorang, Yuhana Damantalm, Afrina Januarista, Sukri.(2016). Faktor Faktor Yang Berhubungan Dengan Kejadian Preeklamsia Pada Ibu Hamil Di Poli Kia Rsu 
Anutapura Palu. Jurnal Kesehatan Tadulako Vol 2 No 1, Januari 2016: 1-75

Http://Jurnal.Untad.Ac.Id/Jurnal/Index.Php/Healthytadulako/Ar ticle/View/5744/4510 Di Akses Pada Tanggal 13 Oktober 2019. 